\title{
Extensional collapse along the Sevier Desert reflection, northern Sevier Desert basin, western United States: Comment and Reply
}

\section{COMMENT}

\author{
Mark H. Anders, Nicholas Christie-Blick, Stewart Wills \\ Department of Earth and Environmental Sciences and Lamont-Doherty Earth \\ Observatory, Columbia University, Palisades, New York 10964-8000
}

Coogan and DeCelles (1996) provided a welcome addition to the debate on the Sevier Desert reflection. The evidence and arguments presented on the nature of this subsurface feature merit particular scrutiny, as they bear directly on a firstorder issue in tectonics: the mechanical paradox of low-angle normal faults. Field geologists have argued that in some cases such faults must have moved at dips of $20^{\circ}$ or less; tectonophysicists maintain that such interpretations are inconsistent with our present knowledge of rock mechanics, and seismologists have yet to record a single earthquake that can be related unequivocally to slip on a low-angle normal fault. If, as Coogan and DeCelles (1996) and others have argued, the seismically imaged Sevier Desert reflection of west-central Utah is a rooted detachment fault with as much as $39 \mathrm{~km}$ of top-to-the-west slip, the seismic-reflection geometry effectively requires normal-sense slip on a surface dipping $11^{\circ}$. We believe, however, that geometry can also support alternative interpretations.

As Coogan and DeCelles recognized, a key to the distinction between detachment and nondetachment interpretations is the geometric relation at the western margin of the basin, between east-tilted Proterozoic and Paleozoic rocks of the Cricket Mountains block and overlying Tertiary sediments of the Sevier Desert basin. Eastward fanning of Tertiary strata above this block would be consistent with gradual tilting above a rooted detachment fault (as inferred by Coogan and DeCelles, 1996); in contrast, the absence of fanning or of significant stratal dip in Tertiary sediments would be consistent with a combination of alternative basin-forming mechanisms, including regional subsidence, offset along high-angle normal faults, and the development of erosional topography at the margin of the late Mesozoic-early Tertiary orogen. Our own analysis of regional seismic data within the basin suggests that in this critical area the evidence is at best equivocal, but that it tends to support the second view. We do not believe that the Cricket Mountains block was appreciably tilted during sedimentation in the Sevier Desert basin.

Central to the interpretation of Coogan and DeCelles (1996) is reflection geometry evident in profile GSI 25 in the vicinity of the Gulf Oil Gronning \#1 well, and specifically a panel of reflections that between $1.4 \mathrm{~s}$ and $1.7 \mathrm{~s}$ twoway travel time dip between $16^{\circ}$ and $17^{\circ}$ to the east and appear to terminate downward against the inferred detachment fault (Fig. la; location shown in their Fig. 1). If the reflections were primary, similar geometry might be expected on other profiles in the same area. Curiously, however, the dipping reflections are virtually absent on profile Pan Canadian 1 (Fig. lb), which directly crosses the Gronning \#1 well and intersects GSI 25 at about $50^{\circ}$ (location shown in Fig. 1 of Coogan and DeCelles, 1996). We examined the recovered core from near the bottom of the Gronning \#1 well (between $2107 \mathrm{~m}$ and $2448 \mathrm{~m}$ ) and found that dips in cross-stratified sandstone range from $3^{\circ}$ to $14^{\circ}$, with no discernible downhole trend; dips in siltstone range from $5^{\circ}$ to $8^{\circ}$ (average, $6^{\circ}$ ), markedly less than the $16^{\circ}-17^{\circ}$ dip estimated by Coogan and DeCelles. Although no vertical deviation data are available for the well, we note that in profile Pan Canadian 1, reflections at the same level in the vicinity of the Gronning \#1 well dip gently eastward at about $4^{\circ}$ (A in Fig. lb, assuming a $3180 \mathrm{~m} / \mathrm{s}$ average velocity and correcting for apparent dip to the same azimuth as GSI 25), consistent with the estimate obtained from the core. We suggest, therefore, that the dipping reflections may not be primary, but may instead be multiples related to dense, layered basalts higher in the succession ( 0.7 to $0.9 \mathrm{~s}$ two-way travel time at the Gronning \#1 well). The prominent reflection at A in Figure $\mathrm{lb}$ can be traced westward to its intersection with a reflection that dips at about $25^{\circ}$ east (labeled B in Fig. 1), and which Von Tish et al. (1985) erroneously interpreted as Oligocene due to a miscorrelation with the Gronning \#1 well (Anders et al., 1995). In marked contrast to the stratal fanning inferred by Coogan and DeCelles, this low-angle onlapping

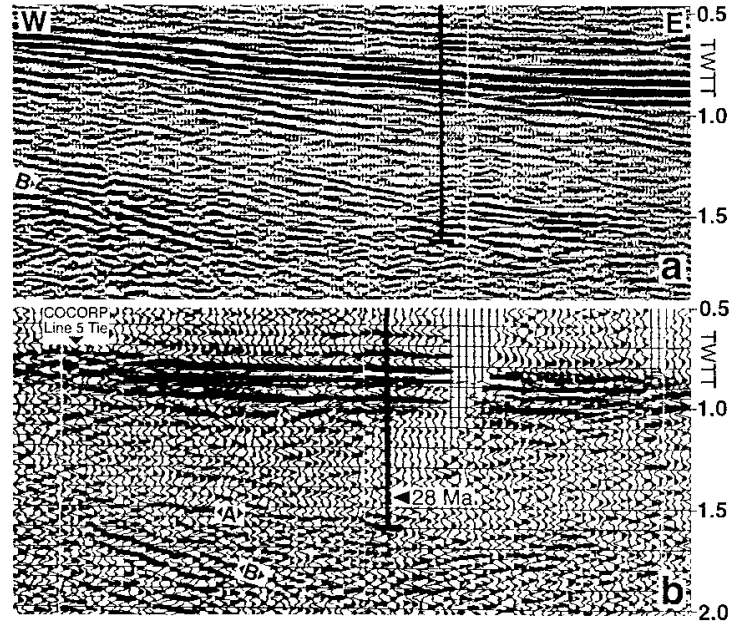

Figure 1. Seismic reflection section GSI 25 (a) and Pan Canadian I (b), modified from Mitchell and McDonald (1987). Gulf Oil Gronning \#1 well (bold vertical line), shown in both figures, bottoms in the Tertiary at $2458 \mathrm{~m}$. Reflection $A$ is one of a series of reflections that onlaps reflection $B$.

geometry can be seen on all appropriately oriented seismic sections in the southern part of the basin (where no tilted basaltic rocks are present higher in the succession). We suggest that the onlap surface is the unconformable base of the Tertiary basin.

The existence of high-angle normal faults that appear to sole or terminate downward into the Sevier Desert reflection and evidence for stratal thickening toward such faults are indeed consistent with the presence of a rooted detachment fault that was active during sedimentation (Coogan and DeCelles, 1996). However, the same geometry is also consistent with the widespread presence within the basin of lacustrine evaporites as much as $1.5 \mathrm{~km}$ thick (Argonaut Energy Federal \#1 well; Mitchell, 1979; Gary Mitchell, personal commun., 1997). Salt structures associated with prominent velocity pull-ups, and illustrated in Figure 2a of Coogan and DeCelles (1996), are prima facie evidence for salt mobility.

Coogan and DeCelles adroitly summarize the circumstantial evidence for a detachment at the Paleozoic-Tertiary contact, but we do not believe that they pay sufficient attention to data from the contact itself. No evidence for deformation has yet been found at this surface in any industry well in the basin (Anders and Christie-Blick, 1994). This includes the 10-m-thick unit at the Paleozoic-Tertiary contact in the Argonaut Federal \#1 well (Mitchell, 1979), which Coogan and DeCelles characterize as a "possible fault breccia." We have examined samples, and concur with Mitchell's (1979) conclusion that it is a depositional conglomerate.

\section{REFERENCES CITED}

Anders, M. H., and Christie-Blick, N., 1994, Is the Sevier Desert reflection of west-central Utah a normal fault? Geology, v. 22, p. 771-774.

Anders, M. H., Christie-Blick, N., and Wills, S., 1995, Is the Sevier Desert reflection of west-central Utah a normal fault?: Reply: Geology, v. 23, p. 670

Coogan, J. C., and DeCelles, P. G., 1996, Extensional collapse along the Sevier Desert reflection, northern Sevier Desert basin, western United States: Geology, v. 24, p. 933-936.

Mitchell, G. C. 1979, Stratigraphy and regional implications of the Argonaut Energy No. 1 Federal, Millard County, Utah, in Newman, G. W., and Goode, H. D., eds., Basin and Range Symposium and Great Basin Field Conference: Denver, Colorado, Rocky Mountain Association of Geologists, p. 503-514.

Mitchell, G. C., and McDonald, R. E., 1987, Subsurface Tertiary strata, origin, depositional model and hydrocarbon exploration potential of the Sevier Desert basin, west central Utah, in Kopp, R. S., and Cohenour, R. E., eds., Cenozoic geology of western Utah-Sites for precious metal and hydrocarbon accumulations: Utah Geological Association Publication, v. 16, p. 533-556.

Von Tish, D. B., Allmendinger, R. W., and Sharp, J. W., 1985, History of Cenozoic extension in central Sevier Desert, west-central Utah, from COCORP seismic reflection data: American Association of Petroleum Geologists Bulletin, v. 69, p. 1077-1087. 


\section{REPLY}

James C. Coogan*, Peter G. DeCelles

Department of Geosciences, University of Arizona, Tucson, Arizona 85721

In their comparison of two seismic reflection profiles across the western margin of the Sevier Desert basin, Anders et al. fall victims to a classic pitfall of seismic interpretation - the misinterpretation of multiples as primary stratal reflections. Their error lies in ignoring the acquisition parameters of the two data sets and overlooking fundamental characteristics of long-path multiples. The industry profiles in their Figure 1 are published in Mitchell and McDonald (1987) for detailed inspection. We focus on two attributes of long-path multiples to document the error in Anders et al.'s analysis: the effects of fold on multiple identification and attenuation, and the periodicity of multiples.

GSI 25 (Fig. 1a; all figure references are to Figure 1 of Anders et al.'s Comment) provides better resolution of steeper dipping stratal reflections largely because it is a more recent (acquired in 1980) and redundant 24-fold data set compared to the 12-fold Pan Canadian 1 profile (Fig. 1b; 1974 earliest published processing). In standard common depth point (CDP) processing, longperiod multiples are identified during velocity analysis by their slower stacking velocities relative to coincident primary reflections. Increased CDP fold provides increased sampling for improved velocity analysis, and it contributes to multiple cancellation and primary reinforcement when the increased number of channels are summed, using the refined velocities, into a single stacked trace (Telford et al., 1976, p. 288, 390). The absence of event A on GSI 25 and the enhancement of the steeper dipping coincident reflections indicate that event $\mathrm{A}$ is a multiple that is attenuated with increasing fold, whereas the steeper events are primary stratal reflections. Other acquisition and processing attributes undoubtedly contribute to the increased resolution of GSI 25 , but their effects can only be judged through comparative reprocessing.

Event A on Pan Canadian 1 (Fig. 1b) has the periodicity of a long-path multiple reflection between the top basalt and a near-surface reflector. Longpath multiples have slightly less than twice the travel time of the primary reflection horizons from which they are generated (Telford et al, 1976, p. 288). The $1.55 \mathrm{~s}$ two-way traveltime of event A at the Gulf well tie is almost twice that of the top basalt reflection at $0.8 \mathrm{~s}$ in Figure $1 \mathrm{~b}$, and this doubling is constant along the event. On GSI 25 (Fig. 1a), in contrast, the steeply dipping reflections that are roughly coincident with event A have about twice the traveltime as the primary basalt reflections at the Gulf well, but they are truncated by the basal basalt reflection just $1.6 \mathrm{~km}$ west of the cropped edge of Figure 1a (Mitchell and McDonald, 1987, Plate 3). These continuous and coherent reflections cannot be long-period multiples generated from the basalt because they are essentially coincident with the basalt reflections at this truncation. They are clearly primary reflections that correlate to dated Oligocene strata near the base of the Gulf well, and their truncation beneath the Pliocene basalt provides concise geometric and kinematic evidence for eastward rotation of the Cricket Mountains block above the Sevier Desert detachment during regional extension.

Interference between multiple and primary reflections is evident just $1 \mathrm{~km}$ east of the cropped edge of Figure 1a (Mitchell and McDonald, 1987, Plate 3), where the basalt locally dips westward. West-dipping multiples underlie the

*Correspondence address: 1950 Glen Ayr Drive, Lakewood, Colorado 80215 basalt starting at twice the traveltime of the top basalt reflection. The multiples cut the steeply east-dipping reflections that tie the Oligocene level in the Gulf well, which further corroborates that the east-dipping reflections are primary.

Our examination of acquisition parameters and multiple characteristics demonstrates that the alternative seismic interpretation offered by Anders et al. is technically unfounded. In addition, their regional tectonic model is not supported by either their current study of core from the Gulf well or the original study of Anders and Christie-Blick (1994), both of which yield only equivocal results. The combination of alternative basin-forming mechanisms that they propose-regional subsidence, block faulting, salt diapirism, and thrust belt paleotopography - are in direct conflict with the regional geology. These mechanisms cannot explain the uplift of the basement and east flank of the Sevier Desert coincident with Miocene basin subsidence and deposition (Allmendinger and Royse, 1995; Linn and Walker, 1995), and the removal of the regional structural and topographic culmination that occupied the Sevier Desert area at the end of Mesozoic-early Tertiary thrusting (DeCelles et al., 1995). Regional reconstructions by Allmendinger et al. (1986) and Royse (1993) demonstrate that the coupled mechanisms of low angle normal faulting along the Sevier Desert detachment and isostatic uplift of the detachment footwall satisfy these constraints.

The apparent mechanical paradox of low-angle normal faults appears to form the basis of Anders et. al.'s disregard of evidence for such faults. The lack of unequivocal earthquake data that they cite is specious, as there are two possible fault plane solutions for any event, and improved analytical methods recently resolved low-angle normal slip events (Rietbrock et al., 1996). A paradox would exist for the general case where the upper crust behaves as an isotropic MohrCoulomb material subject to a simple horizontal extensional stress state. However, the Sevier Desert is certainly a special case. Prior to extension, the Sevier Desert region was underlain by a series of west-dipping thrust planes in Proterozoic and Paleozoic sedimentary rocks that were rooted westward to a midcrustal basement culmination (DeCelles et al., 1995). As a result, other factors such as preexisting anisotropy and isostatically induced flexural stresses (Spencer and Chase, 1989) contributed to low-angle extensional slip along what had been the margin of a topographically high region of crustal thickening.

\section{REFERENCES CITED}

Allmendinger, R. W., and Royse, F., Jr., 1995, Is the Sevier Desert reflection of west-central Utah a normal fault? Comment: Geology, v. 23, p. 669-670.

Allmendinger, R. W., Farmer, H., Hauser, D., Sharp, J. W., Von Tish, D., Oliver, J., and Kaufman, S., 1986, Phanerozoic tectonics of the Basin and Range-Colorado Plateau transition from COCORP data and geologic data: a Review: American Geophysical Union Geodynamics Series, v. 14, p. 257-267.

Anders, M. H., and Christie-Blick, N., 1994, Is the Sevier Desert reflection of west-central Utah a normal fault? Geology, v. 22, p. 771-774.

DeCelles, P. G., Lawton, T. F., and Mitra, G., 1995, Thrust timing, growth of structural culminations, and synorogenic sedimentation in the type Sevier orogenic belt, western United States: Geology, v. 23, p. 699-702.

Linn, J. K., and Walker, J. D., 1995, Preliminary report of fission-track data from the Pavant and Canyon Range thrust sheets and synorogenic conglomerates, Sevier orogenic belt, central Utah: Geological Society of America Abstracts with Program, v. 27, no. 4, p. 43.

Mitchell, G. C., and McDonald, R. E., 1987, Subsurface Tertiary strata, origin, depositional model, and hydrocarbon exploration potential of the Sevier Desert basin, west central Utah: Utah Geological Association Publication 16, p. 533-556.

Rietbrock, A., Tiberi, C., Scherbaum, F., and Lyon-Caen, H., 1996, Seismic slip on a low angle normal fault from the Gulf of Corinth: Evidence from high-resolution cluster analysis of microearthquakes: Geophysical Research Letters, v. 23, p. 1817-1820.

Royse, F., Jr., 1993, Case of the phantom foredeep: Early Cretaceous in western Utah: Geology, v. 21, p. 133-136. Spencer, J. E., and Chase, C. G., 1989, Role of crustal flexure in the initiation of low-angle normal faults and implications for structural evolution of the Basin and Range province: Journal of Geophysical Research, v. 94, p. $1765-1775$.

Telford, W. M., Geldart, L. P., Sheriff, R. E., and Keys, D. A.,1976, Applied geophysics: Cambridge, Cambridge University Press, $860 \mathrm{p}$

\section{Dome-and-keel provinces formed during Paleoproterozoic orogenic collapse-Core complexes, diapirs, or neither?: Examples from the Quadrilátero Ferrífero and the Penokean orogen: Comment and Reply}

\section{COMMENT}

\section{Daniel Holm}

Department of Geology, Kent State University, Kent, Ohio 44242

David Schneider

Department of Earth and Environmental Sciences, Lehigh University, Bethlehem, Pennsylvania 18015

Daniel Lux

Department of Geological Sciences, University of Maine, Orono, Maine 04469
Marshak et al. (1997) have reinterpreted some classic Paleoproterozoic dome-and-keel structures as features formed during episodes of late to postcollisional crustal thinning. This proposed origin provides a new and provocative explanation for features historically considered to have formed under compression. One of the examples used by Marshak et al. (1997) in support of their model is the Republic trough of the southern Lake Superior region. According to their model, vertical rise of the gneiss domes of the southern Lake Superior region caused metamorphism of the mantling metasedimentary rocks. Thermochronologic data obtained by us from the region suggests that, for the most part, 